Yayın Kritiği:

Avrupa Konseyi'nin "Shared Histories for Europe Without Dividing Lines" Adlı Proje Kitabında Osmanlı ve Türk İmajı*

\title{
Esra ÇALIŞKAN
}

Gazi Üniversitesi, Gazi Eğitim Fakültesi, E-posta: caliskannesra@gmail.com

Orcid.org/0000-0002-2105-2833

Article Info

\begin{tabular}{c|l}
\hline $\begin{array}{c}\text { Article Type } \\
\text { Received }\end{array}$ & $\begin{array}{l}\text { Book Review } \\
18.03 .2020 \\
\text { Accepted }\end{array}$ \\
DOI & $10.17497 /$ tuhed.706000 \\
$\begin{array}{c}\text { Corresponding } \\
\text { Author }\end{array}$ & $\begin{array}{l}\text { Esra ÇALIŞKAN } \\
\text { Çalışkan, E. (2020). [Yayın kritiği: Avrupa Konseyi'nin "Shared } \\
\text { Cistories for Europe Without Dividing Lines" Adlı Proje Kitabında } \\
\text { Osmanlı ve Türk İmajı]. Turkish History Education Journal, 9(1), ss. } \\
\text { 284-299. DOI: 10.17497/tuhed.706000 }\end{array}$ \\
\hline
\end{tabular}

* Bu çalışma 10-12 Ekim 2019 tarihinde Bolu'da düzenlenen VI. Uluslararası Tarih Eğitimi sempozyumunda sunulan bildirinin genişletilmiş halidir. 


\section{Giriş}

"Shared Histories for a Europe Without Dividing Lines", "Sınırlar Olmaksızın Avrupa Tarafından Paylaşılan Tarih" adlı Avrupa Birliği Hükümetler Arası Konseyi projesi, Avrupa Konseyi Eğitim Politikası ve Uygulaması (CDPPE) yönetim kurulu tarafından 2010 yılında başlatıldı ve 2014 yılında tamamlandı. 2014 yılının Avrupa'nın günümüzdeki sınırlarının büyük ölçüde çizildiği 1. Dünya Savaşının 100. yıldönümüne rastlaması, kitabın yayımlanma tarihinin önemini arttırmıştır. Projenin önemli sonuçları ve burada sunulan makaleler 900 sayfalık ekitap olarak, Avrupa Konseyi sayfasında okurların erişimine sunulmuştur (SamardžićMarković, 2014, s. 4).

Bu proje ve elimize ulaşan kitap ile yeni milenyumda tarih eğitimini etkili bir şekilde kullanmak amaçlanmıştır. Avrupa bir bütün olarak görülmüş ve Avrupa için ortak bir tarih anlayışı benimsenmiştir. Avrupa'yı sınırları, uyrukları, inançları vb. etkenleri göz önüne alarak ayırmak yerine, bunlar görmezden gelinmiştir. Avrupa'nın anlayışın, toleransın, uzlaşmanın ve barışın ortamı olmasına önem verilmiştir. Tarihsel resim düşmanca değil, karmaşıklığa hoşgörü gösterilerek sunulmuş, yenilikçi bir metot olarak diyalog kullanılmıştır. Avrupalı vatandaşların farklı geçmişlerine saygı duyulması önerilmiştir. Ortak Avrupa tarihi anlayışı ile Avrupa'daki her ülke, toplum, sosyal grup ve din için ortak bir eğitim kombinasyonu oluşturulmuştur. Bu anlamda çoklu bakış açısı (multiperspectivity) ön plana çıkmış ve tarih çok yönlü bir ayna rolünü üstlenmiştir (Samardžić-Marković, 2014, s. 5-7).

Avrupa'da ortak tarih anlayışının oluşturulması adına yapılan projede Osmanlı ve Türkler de yer almaktaydı. Şüphesiz bunun öncelikli nedeni Avrupa ile uzun yıllar sınır komşusu olmaları ve tarihsel etkileşimlerinin oldukça fazla olmasıydı. Kitap bizlere Avrupa'nın Osmanlı ve Türkler hakkındaki fikir ve ön yargılarını da sunmaktaydı. Bu çalışma ile proje ve kitapta oluşturulan Osmanlı ve Türk imajını belirtmeye çalışacağız. Projede Türk temsilciler de çalıştı ve makaleleri yayımlandı. Kitaptaki konu başııkları dört bölümden oluşmaktadır. Bunlar Sanayi Devrimi'nin etkileri, eğitimin gelişimi, sanat tarihine yansıdığı kadarıyla insan hakları, Avrupa ve dünya şeklinde sıralanmıştır. Malta öğrencileri için yapılan proje deneyi ise bizi konumuz hakkında aydınlatan bölümdür.

Tarih eğitimi alanında, Avrupa Birliği'nde Türk algısı adına yapılan önceki çalışmalarda tarih ders kitapları incelenmiştir. Bu alanda yapılan en kapsamlı çalışma Prof. Dr. Ahmet Şimşek editörlüğünde yayımlanan "Dünyada Türk İmajı Tarih Ders Kitaplarındaki Durum" adlı çalışmadır. Bu çalışmada diğer ülkelerin yanında Avrupa Birliği ülkelerinden on iki ülkenin lise tarih ders kitaplarındaki Türk imajına değinilmiştir. Bunun yanında yine tarih eğitimi alanında Alim Davarcı'ya ait "Alman İlk ve Orta Öğretim Tarih Ders Kitaplarında Metodoloji ve Türk İmajı Üzerine Bir Araştırma" adlı yüksek lisans tezi çalışılmıştır.

\section{Sanayi Devriminin Etkileri Bölümünde Osmanlı ve Türkler}

"Shared Histories for Europe without Dividing Lines" kitabında ilk olarak Sanayi Inkılabının Etkileri bölümü yer almaktadır. Bölüm dokuz makaleden oluşmaktadır. Sanayi İnkılabı İngiltere, İsviçre, Belçika, Saksonya ve Kuzey İtalya'da yayılmış, 1960 ve 1970 yıllarında 
sonlanmış, Avrupa'yı derinden etkileyen önemli olaylardan biridir. Bu sürede Avrupa bütünüyle sanayileşmişti ve dünyanın büyük bir bölümünü de etkisi altına almıştı (Kaelbie, 2014, s. 51).

Bölümün üçüncü makalesi bir Türk akademisyen olan Berrin Ceylan Ataman'a ait olması bakımından dikkat çekmektedir. Ataman'ın (2014) makalesi Osmanlı Devleti'nin Sanayi İnkılabı dönemindeki durumuna ışık tutmaktadır. Sanayi İnkılabı, Osmanlı Devleti'nin komşu sınırlarına kadar yayılmış ve devleti ekonomik olarak sarsan bir hadiseydi. On sekizinci yüzyılın ortasında Avrupa bir madde krizi geçirmiş ve Osmanlı Devleti'nin demografik ve yüzey zenginlikleri Avrupa'ya bir pazar açmıştı. Ancak milliyetçi akımların etkisinde olan Osmanlı Devleti teknolojik gelişmelere uyum sağlayamayarak dağılma sürecine girdi. Avrupa, Osmanlı'ya düşük fiyatlı ürünler sunuyor ve ham madde ihraç ediyordu. Bu durum Duyun-u Umumiye'nin kuruluşuna da zemin hazırlamıştı (s.175).

Ataman (2014) Osmanlı Devleti'nin, Sanayi Devrimi sırasında ilerleyememesini bir işçi sınıfının oluşmamasına bağlamıştır. Osmanlı Devleti'nde kiralık ve günlük işçiler mevcuttu. İş̧i iş veren gibi sosyal sınıfların oluşmaması Sanayi İnkılabına ayak uydurulmasına engel niteliğindeydi. Ayrıca sendikalaşmaya da izin verilmiyordu. Türkiye Cumhuriyeti'nin kurulmasıyla Osmanlı Devleti'nin sona erdiğini ancak birçok sisteminin Türkiye'ye miras kaldığını vurgulamaktadır. Özellikle iş hayatına dair yasal düzenlemeler buna dahildir. Osmanlı'dan Türkiye'ye geçişin bir mola veya radikal bir değişim niteliği gösterdiği belirtilmiştir (s. 175).

Kitapta, Türkiye'de olduğu gibi Balkanların da Sanayi İnkılabına ayak uyduramamalarında Osmanlı Devleti'nin etkisi olduğu savunulmuştur. Balkanlar 18. ve 19. yüzyılda Sanayi İnkılabının etkisinden uzak kalmıştı çünkü o dönem Avusturya ve Osmanlı’ya karşı siyasi bağımsızlıklarını kazanma uğraşındaydılar. Teknolojik gelişmelere ayak uydurmak yerine bu mücadelelerle uğraşmış ve sonuç olarak sanayi devrimine ayak uyduramamışlardı (Manea, 2014, s. 203).

Sanayileşme konusunda Türkiye sık sık Balkanlar ile ortak konularda yer aldı. Batı Avrupa ülkeleriyle karşılaştırıldığında, Güneydoğu Avrupa'daki sanayileşme çok gecikmişti. Burada tamamlanmamış bir Sanayi İnkılabından bahsedebiliriz. Romanya, Hırvatistan ve Slovenya'da sanayileşmenin ilk aşaması 1860'lara dayanmaktaydı; Sırbistan'da 1880'lerde; Bulgaristan, Yunanistan ve Bosna Hersek'te 1890'larda ivme kazandı. Ülkeleri, kişi başına düşen sanayi üretiminin ortalama seviyesine göre sıralarsak, 1911'de Romanya'yı sırasıyla Hırvatistan / Slovenya, Bulgaristan, Bosna Hersek, Sırbistan, Eski Yugoslav Makedonya Cumhuriyeti izledi. Bu Balkan ülkelerinin ardından Türkiye sıralamada yer almış, Türkiye'yi Karadağ ve Arnavutluk izlemiştir. Ancak Türkiye ve Balkan ülkeleri, kendi ekonomik gelişmeleri sırasında gelişmiş kapitalist ülkelerin elde ettiği kişi başına sanayi üretiminin çok gerisinde kaldı. Balkan ülkelerinin biri dahi, íkinci Dünya Savaşı ile gelişmiş bir sanayi ülkesinin ekonomik aşamasına ulaşmayı başaramadı (Manea, 2014, s. 200).

Makalede Balkan devletlerinin İngiliz Sanayi İnkılabı modelini takip etmemeleri eleştirel bir şekilde ele alınmıştır. İngiliz Sanayi İnkılabının (18. ve 19. yüzyıl) temeli olan pamuk endüstrisi Balkanlar'da düşüktü. Başlangıçta, Türkiye ve Bulgaristan yünlü tekstil 
endüstrisinde lider konumundaydı. Ancak Balkanlardaki tamamlanmamış Sanayi Devrimi, sermaye yetersizliği ve düşük sanayi çıktısı koşullarında yavaş yavaş gelişti ve bu hızlı gelişen sanayilere kıyasla yetersiz kaldı (Manea, 2014, s. 200-201).

\section{Eğitimin Gelişimi Bölümünde Osmanlı ve Türkler}

Kitabın ikinci bölümü on bir makaleden oluşmaktadır. Bu bölümde eğitimin gelişiminden bahsedilmiş ve Avrupa' daki eğitime odaklanılmıştır. Avrupa eğitim pratiği etkisini dünya çapında farklı zamanlarda yaymış, aynı zamanda coğrafi ve kültürel sınırlarının dışından gelen sistemleri ve uygulamaları da kabul etmiş ve onlardan etkilenmişti. Avrupa içindeki eğitim tarihinin etkileşimlerini göz önünde bulundurarak, paylaşılan bir Avrupa tarihinden bahsedebiliriz. Burada batı kültürü olarak adlandırılan ve dünya hegemonyasını yitirmiş Avrupa tarihinin aslında daha evrensel bir kültürle karışarak oluşmuş Avrupa kimliğini dikkate almamız talep ediliyor. Karışılan ve Avrupa kimliğini besleyen bu kültürlere bakıldığında özellikle Rusya, Kafkasya bölgesi ve Türkiye ile etkileşimde bulunulduğu belirtilmiştir. Burada geçmişten gelen bir mirastan bahsedildiği için Türkiye ile Osmanlı Devleti de kastedilmiştir. Çünkü Avrupa'da Türkiye, Osmanlı Devleti'nin halef devleti olarak görülmektedir. Yani Osmanlı ve Türkiye Avrupa'nın evrensel kültürlerle iletişimini temsil etmekte, Avrupa'nın tarih ve kültürünü oluşturmada katkı sağlayan ülkeler arasında yer almaktadır (The Development of Education, A Brief Introductıon, 2014, s. 224).

Başta belirttiğimiz gibi paylaşılan tarihten kasıt, Avrupa'da sınırları olmaksızın bir Avrupa tarihi oluşturma anlayışıdır. Bu tarihe yakın coğrafyanın katkıları da göz önüne alınmıştır. Ancak her ne kadar sınırsal yakınlık belirtilerek Rusya, Türkiye ve Kafkaslar örnek verilmiş olsa da Avrupa fikrine tarihsel ve kültürel yaklaşım sadece mekânsal sınırlara ve bundan önce zamansal sınırlara bağlanmamış, Avrupa'nın doğduğu anla ilgili bir fikir birliği eksikliği olsa da kökenini ve kimliğini birçok medeniyetin oluşturduğu belirtilmiştir (The Development of Education, A Brief Introductıon, 2014, s. 225).

Kitapta bu medeniyetler şu şekilde sıralanmıştır:

- Greko-Latin antikliği, dilsel mirası ve temel özgürlük kavramları;

- Latin dilinin yanı sıra adalet, hukuk ve siyasi örgütlenmenin temellerinin borçlu olunduğu Roma;

- Hristiyanlığın yayıımasının Avrupa'da modernite için bir çıkış noktası sunması;

- Orta Çağ modernleşme sürecindeki sekülerizm, Rönesans ve Aydınlanmanın eğitim ve kültürde hümanizm kavramı ile eşitlik, kardeşlik ve özgürlük değerlerini geliştirmesi;

- Çeşitliliğin birlik içinde yerleşimi: Latin Avrupa; Germen Avrupa; Bizans Avrupası; Slav Avrupa; İslami Avrupa;

- Post modernite (The Development of Education, A Brief Introduction, 2014, s. 225).

\section{Sanat Tarihine Yansıdığı Kadarıyla İnsan Hakları Bölümünde Osmanlı ve Türkler}

Kitabın üçüncü bölümünde sanata yer verilmiş ve "insan haklarına yansıdığı kadarıyla sanat tarihi" başlığı altında açıklanmıştır. Bölüm on bir makaleden oluşmaktadır. Balkanlardaki Osmanlı Devleti'ne ait mimari eserlere de dikkat çekilmiştir. Bunlardan en önemlilerinden biri 
de Bosna-Hersek'te bulunan Mostar köprüsüdür. Kitapta verilen bilgilerde köprünün 16. Yüzyılda ünlü Osmanlı Mimarı Mimar Sinan'ın öğrencisi olan Mimar Hayrettin tarafından yapıldığı ve Balkanlar'daki en önemli Osmanlı mimarisi olabileceğine değinilmiştir. Köprünün Sultan Süleyman tarafından yaptırıldığı ve Müslümanlar ile Hristiyan dünyası arasında sembolik bir köprü olduğunun altı çizilmiştir (Welzel, 2014, s. 464).

Mimari alanda Osmanlı Devleti'nin anıldığı bir diğer yer ise Köln Merkez Camisi'dir. Köln de yaşayan halk Köln Katedrali'nin güzelliğinde bir yerde ibadet etmek istediklerini belirtince burada Müslümanlar için ilginç mimari özellikleri sahip bir camii tasarlandı. Camiyi tasarlayan mimarlar Gottfried Böhm ve oğlu Paul Böhm tasarıda Osmanlı mimari motiflerini benimsemişlerdir. Binada kubbe ve iki minare kullanılmıştır. İki minarenin yüksekliği 55 metredir (Welzel, 2014, s. 468).

\section{Avrupa ve Dünya Bölümünde Osmanlı ve Türkler}

Kitabın son bölümü olan "Avrupa ve Dünya" bildiri konumuz hakkında oldukça aydınlatıcı bilgilere ulaşabilmekteyiz. Bu bölüm yirmi bir makaleden oluşmaktadır. Bölümde yer alan makalede Avrupa'nın ikinci bin yılın yarısına kadar istila eden değil, istila edilen konumunda olduğu belirtilmiştir. Bu istila eden devletlere örnek olarak üç devlet verilmiştir. Moğol Devleti, Atın Orda Devleti ve Osmanlı Devleti. Moğol baskınlarının Kiev, Polonya, Macaristan ve Hırvatistan'a kadar yayıldığı, Altın Orda Hanlıklarının, Güney Rusya'nın büyük bölümlerini ele geçirdiği belirtilmiştir. Osmanlı Devleti'nin de 1453'te İstanbul'a (Konstantinopolis) ulaştığı ve Güneydoğu Avrupa'da ilerlemeye devam ettikleri belirtilmiştir (Vries, 2014, s. 603). Burada dikkatimizi çeken Osmanlı ilerleyişinin Moğol istilası ile aynı görülmesidir. Kullanılan kelime "invade" "istila" kelimesidir. Yani Osmanlı ilerleyişi işgal ve istila olarak görülmüş, Moğolların ilerleyişi ile ayırt edilmemiştir.

Avrupa varlığının dünyanın diğer yerlerindeki etkisi anlatılırken Amerika, Afrika, Babür, Çin, Japonya, Kore etkileriyle birlikte Osmanlı üzerindeki etkilerinden de bahsedilmektedir. Yazar burada Avrupalıların Osmanlı Devleti'nde 18. yüzyıla kadar istedikleri gibi yaşamakta oldukça özgür olduklarını belirtmiştir. Bunun nedenini de Osmanlı yöneticilerinin kendilerine güvenmelerine bağlamıştır. Osmanlı Devleti Batı tüccarlarını yönetimleri için doğrudan bir tehdit olmadıkça desteklemişlerdi (Vries, 2014, s. 874).

Vries (2014) makalesinde yönetimini üç kıtaya yaymış olan Osmanlı Devleti'nin yıkıldıktan sonra 1923 'te tekrar kurulduğunu belirtmektedir. Bunu başaran halef devletlerden biri hala iki kıtaya yayılmış olan Türkiye idi. Burada Türkiye'nin Osmanlı devleti haleflerinden olduğu söylenmiştir. Türkiye'nin, Osmanlı Devleti'nin devamı olarak görülmesi tekrar vurgulanmıştır. Avrupa'ya yapılan göçler anlatıldığında Osmanlı Devleti dönemindeki göçlerden de bahsedilmiştir. Makalede belirtilenlere göre Osmanlı Devleti'nin Avrupa'daki sınırlarına birkaç on bin kişi göç etmişti. Ancak kesin olan sayılar hakkında yeterli veri elde edilememiştir (s. 878).

Avrupa'nın, Orta Çağ döneminde dünyanın diğer bölgelerine sunacağı fazla bir şeyi yoktu. Bu dönemde Avrupa, Asya ve onun oryantal lükslerinden etkilenmeye devam etti. Bunlar genellikle ipek Yolu olarak bilinen ticaret yolları ağıyla Avrupa'ya ulaştı. Ancak 13. yüzyılda Uzak Doğu ve Avrupa arasındaki bağlantılar koptu. Bunların nedenlerine bakıldığında 
ise üç sebep sıralanmıştır. Birincisi Kara ölümün çıkması, ikincisi Çin'de Ming'in yükselişi ve üçüncü olarak da Orta Doğu ve Balkanlarda Osmanlı Devleti'nin hâkim olmasıydı. Bu üç unsur Avrupa ile Uzak Doğu arasındaki bağlantıyı koparmıştı. Sonrasında ise Avrupa'nın, Amerika'yı ve Cape Rotasını keşfetmesi ile Uzak Doğu'ya olan karasal bağlantıların önemi yavaş yavaş azaldı (Vries, 2014, s. 882).

Makalede Avrupa da ticari gelişim anlatılırken de Osmanlı Devleti'ne değinilmiştir. Burada belirtilenlere göre, 19. yüzyılda küresel ekonomik entegrasyon tamamen yeni boyutlara büründü. Avrupa'da devlet inşası, ticaretin serbestleşmesi, gelirlerin artması, demiryollarının ve buharlı gemilerin gelmesi uluslararası ticareti hızlandırdı. Atlantik'i çevreleyen ekonomiler sıkı sıkıya bütünleşti. Büyük Asya ekonomileri de Batılılar tarafından işletilen küresel ticaret ağlarına dahil edildi ve daha istikrarlı bir şekilde ilerledi. Burada Osmanlı İmparatorluğu, Çin ve Japonya'nın eşitsiz antlaşmalar ile sınırlarını genişlettikleri belirtilmiş ancak bu anlaşmalar ve olaylar açıklanmamıştır. Süveyş Kanalı ve Panama Kanalı ayrıca dünyanın küçülmesine yardımcı oldu. Afrika'da yaşam onlar için daha az sağlıksız hale gelir gelmez, Avrupalılar bölgeyi paylaşmaya başladılar (Vries, 2014, s. 883).

Weber için "Batı" rasyonelleşmesi, modern bilim ve teknolojide, modern hukuki ve bürokratik devlette ve modern kapitalizmde tam anlamıyla gelişti. Bunların üçü de Avrupa tarihinin ürünüdür. Avrupa'nın dünyanın geri kalanı üzerindeki etkisinin, Batı́nın yükselişinin merkezinde olduğu gerçeğini göz önüne aldığımız zaman, Avrupalı olmayan toplumların Avrupa'nın rasyonalizasyonuna yaptıkları katkılara da dikkat göstermeliyiz. Burada bildiğimiz modern bilimin Avrupa'da ortaya çıktığına, ancak içinde rol oynayan birçok unsur, kavram, teknik ve eserlerin başka bir yerden Avrupa'ya geldiğine değinilmiştir. Bu katkılar özellikle Müslüman dünyadan, Çin'den ve Hindistan'dan sağlanmıştı. Modern bir devlet, profesyonel bir bürokrasi demekti. Çin bunu Avrupalılardan önce keşfetmişti. Yeniçeri teşkilatı olan Osmanlı İmparatorluğu'nun zaten profesyonel bir ordusu vardı. Ordu sistemiyle de Avrupa rasyonalizasyonuna katkısı sağlamıştı. Hukuk alanında ise Romalılardan esinlenilmişti. Yazar burada Avrupa'nın modernleşmenin liderliğini yaparak örnek olmasına rağmen birçok sistemi yine başka toplumları örnek alarak geliştirdiklerini belirtmiştir (Vries, 2014, s. 887).

Criacono (2014) kitapta yer alan makalesinde 17. yüzyılda Avrupalı ticari şirketler ile Avrupalı olmayan kurumlar arasında hassas bir oyun geliştiğinden bahsetmektedir. Burada "non-European institutional bodies", "Avrupalı olmayan kurumlar" ifadesi kullanılmıs ve buna örnek olarak iki ülke Osmanlı Devleti ve Japonya örnek verilmiştir. Osmanlı ve Japonya Avrupalıların kaynaklarını sömürmelerine ve kendilerine avantajlı diplomatik stratejiler geliştirmelerine izin veren zayıf kurumlar olarak ifade edilmiştir (s. 715). Yani Osmanlı Devleti ve Japonya yarı sömürge devleti olarak makalede yer almışlardır. Burada dikkati çeken bir diğer ifade de "Avrupalı olmayan kurumlar" ifadesidir. Bu ifade ile aslında Avrupa sınırları dışında yer alan ülkeler kastedilmiştir. Ancak bunun yerine kullanılan "Avrupalı olmayan" ifadesi negatif bir anlam barındırmakta Avrupalılığa bir üstünlük atfetmektedir.

Endüstriyel ekonomiye geçiş, özellikle de Avrupa sanayileşmesinin küresel olarak sosyal ve ekonomik dengeye etkisi birçok tarihe zengin içerikli bir konu olmuştur. Özellikle de ekonomik bakış açısıyla ele alınmıştır. Bu anlamda "Avrupa kendini diğer kıtalara neden ve nasıl dayattı?" sorusuna cevap aranmıştır. Sömürgecilik sonrası tarihçilik Avrupa karşıtı 
söylemlerden etkilenmiş, Batı ekonomilerinin sosyal ve ekonomik etkilerine dikkat çekilmiştir. Bu etki Avrupalı olmayan(!) devletleri ve kurumları doğal gelişimlerinden saptırmıştı. Birçok ülke batıdan daha fakir hale gelmişti. 19. yüzyılda boşluk daha da artmıştı (Criacono, 2014, s. 716). Osmanlı Devleti Endüstriyel ekonomiye uyum sağlayamayan ve Avrupa dayatmasıyla karşılaşan ülkeler arasında yer almaktaydı. Çünkü bu olumsuz etki özellikle Avrupa sınırları dışındaki ülkeleri etkilemekteydi.

Batıdan daha fakir hale gelen, Avrupa dayatmasıyla karşılaşan, sosyal ve ekonomik olarak etkilenen ülkelere örnek olarak Osmanlı Devleti, İspanya, Japonya ve Hindistan verilmiştir. Bunu açıklamak için Osmanlı Devleti ile verilen örnekte Osmanlı pamuğu konu alınmıştır. Osmanlı Devleti pamuklu kumaşlar üreten ve tüm Orta Doğu'ya ve hatta Avrupa'ya pamuk iplikleri ihraç eden bir devlet konumundayken, 19. yüzyılın ikinci yarısında sadece ham pamuk ihracatçısı oldu. Burada Avrupa hükümetleri ve halkı arasında, gelişmiş Avrupa'ya kıyasla Asya, kendi beceriksiz ve despotik kurumlarının öncüsü olarak görülmüştür. Geri kalmış ve despotik olan Asya'ya kıyasla Avrupa'ya gelişmiş toplumu ve kurumlarıyla üstünlük atfedilmiştir (Criacono, 2014, s. 717).

Kitabın son bölümünde yer alan Juneja'nın (2014) makalesinde İslam sanatının Batıya taşınmasından da bahsedilmiştir. Seyahat, diplomasi, ticaret ve misyonerlik girişimi, Batı seçkinleri tarafından nesnelerin toplandığı ve Avrupa'ya getirildiği kanallar olmuştur. Hareketlilik, merak, koleksiyonculuk tutkusu, günümüzde müzelerde gördüğümüz İslâm sanatının bir parçasını oluşturan kilim, tekstil, fildişi, bronz gibi nesnelerin büyük kısmının bu kanaldan geldiği anlamına geliyordu. Fetih, sömürgecilik, arkeolojik şirketler ve armağanlar, İslâm sanatının Avrupa'ya seyahat ettiği bir başka yolu oluşturdu. Bu anlamda verilen en çarpıcı örnek ise Mshatta Sarayı'nın kalıntılarının Pergamon Müzesine aktarımı olmuştur (Juneja, 2014, s. 736).

Makalede belirtildiği kadarıyla II. Abdülhamid döneminde Bağdat demir yolunun yapımı sırasında Alman arkeologlar demir yolu mühendisleriyle birlikte görev yapmaktaydılar. Bu çalışmalar esnasında Ümeyye (Umayyad) halifelerinin bir kraliyet kışlık saraylarına rastlanıldı. Saray çölün ortasında bugünkü Amman'ın $30 \mathrm{~km}$ güneyindedir. Mshatta sarayı bir deprem ile tahrip olmuş ve 1840 'larda keşfedilene değin kumun altında kalmıştı. Julius Euting gibi bilim adamlarının müdahale etmesi ile, II. Abdülhamid Mshatta Sarayı́nın kalıntılarını Kaiser II William'a hediye olarak sunmuştu. Parçalar yapılmakta olan demiryolu ile taşındı ve ilk olarak Kaiser Wilhelm Müzesi'nde (bugün Bode Müzesi) bir araya getirilip Berlin'e taşındı. 1932 'de, yeniden yapılandırılmış cephenin bugün İslâm sanatına ayrılan bölümünde görülebildiği Pergamon Müzesi'ne transfer edildi (Juneja, 2014, s. 736).

Kaynaklarının sömürülmesin ezin veren ülkeler arasında Osmanlı Devleti de anılmıştır. Burada "colonial development project", "sömürgeci gelişim projesi" ile tarihi boşlukların doldurulduğundan bahsedilmiştir. Bu yaklaşım ile geçmişi ortaya koyan bir müze objesine ulaşılmıştır. Osmanlı Devleti'nin yarı sömürge konumunda olduğunun altı tekrar çizilmiştir (Juneja, 2014, s. 736).

Bu bölümde yer alan bir diğer makalede UNESCO tarafından Güney Doğu Avrupa'da kültürler arası diyaloğun geliştirilmesine yönelik olarak koordine edilen bir proje yer almıştır. 
Proje kapsamında "uzun 19. yüzyıldaki Balkanları, anılarını ve kimliklerini hayal et" sergisi yapılmıştır. Bu projede Güneydoğu Avrupa, uluslararası ve etnik gerilimlerle karakterize bir bölge olarak görülmüştür. Projenin amacı da her devletin kendine özgü ulusal ideallerinin destekçileri olarak algılanan ulusal müzeler arasında bir tür iş birliği başlatmaktı (Mazarakis, 2014, s. 767).

Projenin ismi yapılan tartışmaların sonunda tarihçi Maria Todorova tarafından verildi. Maria Todorova Bulgar asıllı, Bulgar kökeni tarihçisidir. Todorova, Bugünkü Balkanlar'ın şekillenmesinde, birkaç yüzyıl süren ideolojik yapılanmanın, önyargıların ve Batı'dan kaynaklanan çeşitli spesifik ideolojilerin içselleştirilmesinin etkili olduğunu savunmaktadır. Bu algılamaların dış ilişkilerde olması normaldir ancak 19. Yüzyıl Avrupası'nda Balkanlar için daha belirgindi. Çünkü Avrupa'da Aydınlanma ve Sanayi İnkılabı tam ekonomik ve politik genişleme içinde ve romantik bir ruhla sürdürülmekteydi (Mazarakis, 2014, s. 767).

O zamanlar Avrupa, tamamen farklı bir durumla karşı karşıya kalan Osmanlı dünyasıyla daha yakın temas halinde oldu ve Balkanlar görmezden gelindi. Nitekim "Balkanlar" Güneydoğu Avrupa için kullanılan bir isimdi ve olumsuz bir klişe olarak algılanan bir sözdü. "Güneydoğu Avrupa" yerine "Balkanlar" kelimesinin seçilmesi bu nedenle önemlidir. Balkanlar bir yapıyı temsil etmekteydi. Balkanlar Doğu Avrupa'nın negatif olarak algılanan bir sterotipidir. Balkan kelimesi gerçeklik ve hayal gücüne kıyasla gerçeklikle daha az ilgisi olan bir kelimedir. Tam da bu nedenle serginin adı olarak seçildiği belirtilmiştir (Mazarakis, 2014, s. 767).

Projede Türkiye ve Kıbrıs'tan temsilciler de yer aldılar. Kıbrıs'ı temsilen Leventis Kıbrıs Belediye Müzesi katıldı. Temsilciler adanın halen çözülememiş siyasi sorunları ile kısıtlandıklarını belirtmişlerdi. Adadaki herhangi bir ulus oluşturma sürecinin, 1970'lerin Türk askeri işgalinden bu yana uygulanan geçici bir ateşkes ile engellendiği belirtilmiştir (Mazarakis, 2014, s. 771). Burada yakın tarihte gerçekleşen ve bizim "Kıbrıs Barış Harekâtı” şeklinde adlandırdığımız olay yine Moğollar örneğinde olduğu gibi işgal ve istila anlamına gelen "invasion" kelimesi ile anlatılmıştır. Yani Avrupa'da Kıbrıs Harekâtı işgal olarak görülmektedir.

Aynı projede "Tarihi Kullanma" ve "Kahramanlar ile Anti Kahramanlar" bölümleri oluşturulmuştur. Anti kahramanlar bölümü oluşturulurken Osmanlı padişahlarının olumsuz imajlarından bahsedildiğine değinilmiş ancak makalede bunların kimler olduğuna belirtilmemiştir. Proje toplantısına katılanlar arasında Sabancı Müzesi temsilcileri de vardı. Ancak, Osmanlı Devleti'ni temsil ettikleri ve diğer bölgesel milliyetçiliklerin geleneksel rakibi olarak görüldükleri için ideolojik tartışmalarda hedef oldular. Bu ifadelerden rahatsız olan Türk temsilciler tepkilerini belirttiler. Bu nedenle müzenin temsilcileri bu konuda projeden çekilmeye karar verdiler. Yalnızca Profesör Tülay Artan, üniversite profesörlüğü temelinde danışmanlık rolünü sürdürdü (Mazarakis, 2014, s. 773).

Yazarımız Batı epistemolojilerini ve perspektiflerini evrensel olarak tanımlamak konusunda dünyada Batı'ya doğru belirgin bir eğilim olduğunu belirtmiştir. Bunun ile ilgili eserler bizzat kendi kıtalarında yazılmış çok sayıda tarihi eser ile açıklanmıştır. Avrupa'nın rasyonalizm, dinamizm ve özgürlüğünün dünyanın diğer bölgeleri için yüksek bir potansiyel taşıdığı benzersiz bir dinamik medeniyet olduğu fikri, diğer ülkelerce açıkça ya da dolaylı 
olarak onaylandı. Batı'nın dışındaki birçok tarihçi, kendi toplumlarının modernizasyonu için gerekli gördükleri bilgileri Batıdan edinmek istiyordu. Bu toplumlara örnek olarak başta Osmanlı İmparatorluğu olmak üzere, Çin, Hindistan, Japonya gibi ülkeler örnek verilmiştir. Böylece "Dünya tarihi" önemini azaltmak yerine, daha belirgin bir duruş kazanmaya başlamıştır. Yani geçmişin yeni vizyonları sıklıkla geleceğe yönelik modernleşme çabalarının anahtarı olarak görülmüştür (Sachsenmaier, 2014, s. 819).

\section{Maltalı Öğrencilere Yönelik Araştırmada Osmanlı ve Türk İmajı}

Çalışmamızın ikinci bölümü “Avrupa ve Dünya” başlığı altında yer alan Yosanna Vella'ya ait bir makalenin analizinden oluşmaktadır. Makalede Malta öğrencilerine yönelik yapılan araştırma yer almaktadır. Avrupa Konseyi ve Euroclio (Avrupa Tarih Eğitimcileri Birliği) tarafından yürütülen tarih eğitimi projesi ile yapılmak istenen "other" diye tarif ettiklerimizi açıklamaktı. Fransız Devrimi veya Birinci Dünya Savaşı gibi daha geleneksel konuların yerine göç ve insan hakları tarihini koymak, insanların insan haklarına saygı duymalarını ya da anavatanlarına yeni gelenlerin kötü durumlarına sempati duymalarını sağlamayacaktı (Vella, 2014, s. 849).

Bu makalede açıklanan araştırmada öğrencilere "16. yy. Osmanlı İmparatorluğu tarihi" konu olarak verildi. Burada amaç öğrenilen konuyu bugünkü Müslüman ve Hristiyanları anlamaya dönüştürmekti (Vella, 2014, s. 850). Müslümanların anlaşılması için örnek olarak Osmanlı Devleti'nin verilmesi de iki yönden destekleyicidir. Birincisi Balkanlar uzun süre Müslümanları ve İslâm’ı Osmanlılar aracılığıyla tanımışlardı. Diğeri ise Batıda Müslüman algısı ile Türk algısının bir olmasıydı. Müslümanlar onlar için Türk demekti. Makalede İstanbul "Konstantin", Osmanlı da "Osmanlı İmparatorluğu" olarak ifade edilmiştir.

Makalede İslamafobi'ye özellikle değinildi. Söz konusu Malta olunca ada Müslüman Araplar ve Türkler ile uzun süreli çatışmaların yaşandığı bir merkezdi. Maltalılar Katolik kültürüne sahiplerdir. Ancak 2002'lerden sonra gelen Afrikalı göçmenlerin ortaya çıkmasıyla adada küçük ama büyüyen bir Müslüman toplulukla, yeni bir durum ile karşı karşıya kalmaktaydılar. Ancak İslam ve Hristiyanlık, her biri kendi inanç, ritüel ve uygulamalarına sahip iki dindi; tarihsel olarak bu iki örgütlü din, iki imparatorluk bloğu tanımlayan toplumsal sistemlerdi. Biri inanan diğeri kafirdi, biri ya gruba ait ya da değildi. Her iki grup da kendilerini ve ötekini tanımlamak için çok benzer terimler kullanmaktaydılar (Vella, 2014, s. 851).

Makalede Maltalılar'ın Müslüman algılarına değinilmiş ve "the term 'Turk' is often used interchangeably with 'Muslim'”' ifadesi kullanılmıştır. Yani Türk ve Müslüman terimleri birbirini karşılayan terimlerdir. Avrupa da Müslüman demek Türk demek ile aynıdır sonucunu tekrar çıkarabiliriz. 18. ve 19. yüzyıllarda edebiyatın ürettiği tabloda "traditional enemy", "the sons of Mohammed" ile karşılık bulmaktaydı. Yani geleneksel düşman Müslüman olanlar demekti. Ayrıca Maltalılar gelen Müslümanların, Maltalıları köleleştirmek ve Kur'an ile İncil'i değiştirmek gibi amaçları olduğunu düşünmekteydiler. Malta'da Müslümanlara yönelik çeşitli küçük ırkçı olaylar, Müslümanlara ilişkin bu ve benzeri betimlemelerin kökleşmesine sebep oluyordu (Vella, 2014, s. 852).

Bu makale, önyargılı ve tek taraflı görüntülerle mücadele etmek için tarih öğretimini araç olarak kullanma girişimini anlatmaktadır. Tarih öğrenme etkinlikleri, 12 ve 13 yaşlarında, 
toplam 74 öğrenciden oluşan üç farklı sekizinci sınıf öğrencisi olan özel bir okulda gerçekleştirildi. Bu sınıflar karma başarıya sahip olanlardan oluşuyordu. Öğrencilerin sosyal geçmişleri homojendi ve ebeveynleri üst ile orta sınıfa mensuptu. Öğrencilerin büyük çoğunluğu Katolikti (Vella, 2014, s. 853).

Çalışma ile Malta toplumundaki Müslümanların olumsuz tasvirleri ele alınmıştır. Yazar, "1565 Büyük Kuşatması” başlığı altında çalışmaya karar verdi. Maltalılar açısından 1560'larda Malta, emperyal genişleme konusunda büyük bir Türk planının parçasıydı. O zamanlar Malta stratejik değere sahipti ve eğer Osmanlılar Malta'yı ele geçirirse, onu güçlerini inşa edebilecekleri bir üs olarak kullanabilirlerdi çünkü Malta Hristiyan Avrupa'ya çok yakındı. Yazarımız, işgalciler olarak Türkler 'in olağan anlatımlarından ziyade, Büyük Osmanlı İmparatorluğu'na giriş dersi olarak ekstra bir ders eklemesi için okul yöneticisinden ve sınıfın tarih öğretmeninden izin almıştı. Böylece öğrencilere farklı bakış açılarını anlayarak Osmanlı İmparatorluğu hakkında bilgi edinme fırsatı verilecekti. Bu çalışma birincil tarihsel kaynakların analizi ile yapıldı (Vella, 2014, s. 853).

Asıl yapılacak dersten birkaç gün önce öğrencilere yazılı olarak cevaplamalarını istedikleri bir soru ödevi verildi. Soru şudur: “16. Yüzyılda, Osmanlı Türklerinin 1565'teki Büyük kuşatmayı kazanmaları durumunda, Malta yaşanılacak nasıl bir yer olurdu? Neden böyle düşünüyorsun?" Birkaç gün sonra Osmanlı İmparatorluğu'nu konu alan bir ders yapıldı. Bu derste öğretmen, Osmanlı İmparatorluğu'nun var olduğu dönemi açıklamak için öğrencilere bir zaman çizelgesi sundu (Vella, 2014, s. 853).

Daha sonra öğrencilere Osmanlı İmparatorluğu ile ilgili öğretmen merkezli bir PowerPoint sunumu izletildi. Bu on dakikalık bir anlatıydı. Tek bir olaya yani i̇stanbul'un (Konstantinopolis) 1453 yılındaki yıkılışına odaklanıldı. Sunum ayrıca farklı dini bağlantıları ve kimlikleri olan kişilerin, Osmanlı İmparatorluğu vatandaşları olarak uzun süre barış içinde birlikte yaşadıklarını ve bu nedenle Osmanlı İmparatorluğu'nun farklı kültürler ile barışın, bir arada bulunmasının en önemli örneklerinden olduğunu açıkladı (Vella, 2014, s. 854).

Öğretmen daha sonra Fatih Sultan Mehmet'in Ayasofya kilisesine girişini anlattı. Tarihçilerin, Fatih Sultan Mehmet'in burada bir avuç toprağı alarak başından aşağı döküp Allah karşısındaki aczini bildirdiğine hem fikir olduklarını açıkladı. Emperyal gücün fiziksel bir örneği olan kilise artık ona aitti. Öğretmen burada Fatih Sultan Mehmet'in Ayasofya'nın büyüklüğünü tanıyan ve onu koruyan bir aydın olarak, Rönesans adamı olduğunu söyledi. Sultan'ın, Meryem Ana ve şehrin koruyucusu olduğunu düşündüğü seraphların imgeleri de dahil olmak üzere, en iyi Hıristiyan mozaiklerinin birçoğunun nasıl kalmasına izin verdiğini yorumladı (Vella, 2014, s. 855).

Bu anlatıdan sonra sınıf dört gruba ayrıldı ve her gruba Osmanlı Imparatorluğu hakkında bir dizi birincil kaynak verildi:

- Eserler Grubu

- Politika Grubu

- Binalar Grubu

- Toplum Grubu 
Yazar aktivitede kullandığı kaynakların seçimini, 2009 yılındaki bir workshopta Türk öğretmenler ile yapmıştı. Bu atölye çalışması sırasında yazar araştırma projesinin amacını açıkladı ve Türk tarih öğretmenlerinden Osmanlı Devleti'nin ihtişamını ve zenginliğini en iyi şekilde temsil eden uygun birincil kaynaklardan seçim yapmasını istedi. Türk tarih öğretmenleri, Osmanlı İmparatorluğu'nun yalnızca olumlu yönlerinin sunulmasının Malta Katolik öğrencilerine önyargılı bir görüş bildirilmesinden endişelendiklerini belirtmişlerdi. Tartışmalardan sonra, Malta'da hâkim olan Osmanlı İmparatorluğu'nun güçlü olumsuz imajı nedeniyle, olumlu yönleri sunarak aslında daha dengeli bir görüşün ortaya çıkacağı sonucuna varmışlardı (Vella, 2014, s. 856).

Malta'da yapılan derste öğrencilere birincil kaynaklar ile birlikte doldurmaları gereken bir tablo verildi. Yirmi dakikalık grup çalışmasının ardından, her grup kendilerine verilen kaynaklardan Osmanlı İmparatorluğu hakkında neler öğrendiklerini tekrar sınıfa bildirdi. Bu dersten birkaç gün sonra, öğrencilerden dersten önce sorulan soruyu yazarak tekrar cevaplamaları istendi. Ders öncesi ve ders sonrası yanıtları analiz etmek için Likert ölçeği kullanıldı (Vella, 2014, s. 858).

Soru: “16. Yüzyılda, Osmanlı Türklerinin 1565'teki Büyük kuşatmayı kazanmaları durumunda, Malta yaşanılacak nasıl bir yer olurdu? Neden böyle düşünüyorsun?"

Tablo 1

Öğrencilerin Dersten Önce ve Dersten Sonra Sorulara Verdiği Yanıtların Sonuçları

\begin{tabular}{cccccc}
\hline & Çok iyi & İyi & Aynı & Kötü & Çok Kötü \\
\hline Dersten Önce & 0 & 1 & 9 & 57 & 7 \\
Dersten Sonra & 0 & 7 & 14 & 43 & 4 \\
\hline
\end{tabular}

Tablo, ders öncesi sonuçlarda ortalama düşüncenin neredeyse "yaşamak için daha kötü bir yer" olduğunu gösterirken, ders sonrası sonuçlarının ortada "aynı" ile "yaşamak için daha kötü bir yer" arasında olduğunu göstermektedir. Bu, deneyin küçük ölçeği göz önüne alındığında sadece bir dersten sonra tutumda hafif bir kayma meydana gelmesi oldukça önemlidir. Yazarımız burada öğretmenin Osmanlı İmparatorluğu lehine heveslerini toplamaya gayret etmesi ve öğrencilerin pozitif cevap için birbirlerinden etkilenmeleri gibi nedenlerin öğrencilerin cevaplarında etkili olabileceğinin altını çizmiştir. Ancak, Osmanlı İmparatorluğu hakkında daha iyi bir görüşe sahip olduklarından ve farkındalıklarının artmasıyla olumlu olasılıkları da değerlendirmelerinden dolayı farklı cevap vermiş olmaları da mümkündür (Vella, 2014, s. 860).

Öğrencilerin, sorularının ikinci bölümünde yer alan "neden?" sorusuna verdiği yanıtlar, öğrencilerin konuyla ilgili düşüncelerine daha fazla ışık tutan nitel verilerin elde edildiği yerdi. Öğrencilerin tepkilerini etkileyen önemli bir endişenin din meselesi olduğu açıktı. Pek çok öğrenciye göre, Malta'nın Türk fethinden sonra daha iyi bir yer olup olmayacağı, Malta'nın dinlerini yaşamalarına izin verip vermeyeceğine bağlıydı. Ders yapılmadan önce bazı öğrenciler Türkler ile ilgili görüşlerini şu şekilde açıklamışlardı: “Çünkü St. John Şövalyeleri kibar ve insancıldır, ancak Türkler acımasızdır. Türklerin yönetiminin kötü olacağını düşünüyorum." "Türkler yönetiminde Malta kötü bir yer olurdu çünkü Türkler 
merhametsizdir. Muhtemelen inancımızı değiştirip bizi köleleştirirlerdi. Ülkemizin mirasına ağır bir darbe vururlardı" (Vella, 2014, s. 861).

Öğrenciler derse katıldıktan sonra Türklerin fethettikleri bölgelerdeki inanışlara hoşgörü gösterdikleri anlatılmasına rağmen din öğrencilerin temel kaygısı olmaya devam etmişti. Onlara göre Türkler kiliseleri yok etmese de onları dönüştürürdü. Osmanlılar muhtemelen daha fazla vergi alacaklar, Katedraller camiye dönüştürülecekti. Türkler hoşgörüye sahip olmalarına rağmen bütün Katolikleri öldüreceklerdi. Maltalılar da başka bir dini daha öğrenmek zorunda kalacaklar ve şimdiye dek yaşadıklarından tamamen farklı bir yaşam tarzına sahip olmaları gerekecekti (Vella, 2014, s. 861).

Osmanlı ve Türkler ile ilgili olumlu bilgilerin verildiği dersten sonra ise halen bir öğrenci bunun yeterli olmadığını düşünmekteydi ve Malta'nın yaşamak için çok daha kötü bir yer olacağı görüşündeydi. Öğrenciye göre Osmanlı Devleti kilisede bulunan Hristiyanların eşyalarının kalmasına izin vermesine rağmen Kiliseyi Camiye dönüştürdü ve insanları köleleri yaptı. Maltalılar da Osmanlı Türklerine çok vergi ödemek zorunda kalacaklardı (Vella, 2014, s. 862).

Tabloya baktığımızda dersten önce veya sonra kimse, "Türklerin kazanması durumunda Malta yaşamak için çok daha iyi bir yer olacaktır" dememiştir. Dersten önce, üç sınıftan sadece bir öğrenci, Türklerin kazanması için Malta'nın yaşamak için daha iyi bir yer olacağını söylemiş. Bu öğrencinin yorumu şu şekildedir: "Türkler iyi insanlar olduğu için yaşamak için daha iyi bir yer olacağını düşünüyorum" Dersten sonra Malta'nın yaşamak için daha iyi bir yer olacağını düşündüklerini söyleyen yedi öğrenci vardı. Onların "Neden?" sorusuna verdikleri bazı cevaplar şunlardı: "Osmanlı Türklerinin çok ilginç bir kültürü olduğu için Malta kültürüne çok daha fazla katkı sağlardı ve mimarisine katkıda bulunurlardı." "Türkler Malta'daki bütün dinlere saygı duyardı, popülasyonun çoğunluğu Hristiyan idi, sadece bazı topluluklar Müslümandı. Türkler popülasyonu değiştirmezdi, her ne olursa olsun dine saygı duyarlardı." "Daha iyi olacağını düşünüyorum çünkü Osmanlılar çok huzurlu ve çalışkan insanlar. Aynı zamanda müzikal ve sanatsal yönden ileriler ve zenginler." "Onlar hakkında biraz bilgi edindikten sonra, onların çok iyi yöneticiler olduklarını ve çok büyük bir imparatorluk olduklarını düşünüyorum. Tek sorun Malta'nın onların monarşisi olmasıydı" (Vella, 2014, s. 862).

Yazara göre bu cevaplar öğrencilerin gerçek düşüncelerinin tamamen değiştiğini garanti etmez ancak öğrencilerin bildirdikleri görüşler dersin etkinlikleri sırasında birincil kaynaklar kullanılarak kazanılmıştı. Dolayısıyla bilginin tarihsel bir durumun anlaşı Imasını sağladığı görülüyor (Vella, 2014, s. 862).

Malta'nın ne daha iyi ne de daha kötü olacağını söyleyen öğrencilerin verdiği sebepler de oldukça aydınlatıcıydı. Dersten önce, basit ve yüzeysel cevaplar verildi: "Din değişse bile, herkes mutlu olmaya devam edeceği için aynı olacaktı" Malta halkının dininin değişip değişmeyeceği konusunda iyi ya da kötü bir değişim olacağı fikrindelerdi: "Sanırım aynı olurdu çünkü belki de Türkler, sadece Maltalıların İslam'a dönmesini isteyecek ve şövalyeler gibi olacaklardı. İslâm'ı kabul etmek ya da etmemek için gerekli şartları yerine getirebilirlerdi." Maltalı bir lider mi yoksa Türk lider mi sorusuna "aynısını" seçtiğini söyleyen bir öğrenci 
tarafından ilginç olduğu kadar milliyetçi bir sebep de verildi. "Büyük Kuşatmayı kazanmaları fark yaratmayacaktı. Ancak Malta'da yaşadığımız için açıkça Malta liderini tercih ederdim. Eğer Müslümanlar Malta'yı ele geçirselerdi, muhtemelen Malta çok zengin olurdu çünkü Müslümanlar Libya'dan gelmişlerdi ve Libya çok zengindir."

Dersten sonra, Malta'nın bir Türk fethinden sonra aynı olacağını düşünenlerin daha fazla sayıda olduğunu görmekteyiz ve bu cevabı verenler tarihsel olarak daha fazla açıklama yapmaktalar. "Aynı olurdu ve Türkler bize farklı şeyler öğretirdi. Aynıyla muamele etmek gibi. Ama sonra muhtemelen dinimizi değiştirmek zorunda kalacaktık. Ingiliz yönetiminde olmayacağımız için muhtemelen şu an İngilizce de konuşmuyor olurduk. Aynı zamanda muhtemelen fakir olanlar da köleleştirilirlerdi." "Şövalyeler Malta'nın iyi bir yer olmasını yardım ettiklerinden dolayı onları tercih ederim. Ancak Osmanlılar Rodos'u fethettiklerinde onlara merhamet göstermişlerdi, muhtemelen Malta için de aynısını yaparlardı. Onlar aynı zamanda Konstantinopolis'i fethettiklerinde de çok fazla merhamet göstermişlerdi." Malta'nın aynı olacağını düşünenlerden birinin de yorumu şu şekildedir: "Osmanlılar ile aynı olurdu ancak din ve yönetim şekli değişirdi. Osmanlılar Malta adasına çok fazla kültür taşırlardı ve Türkler iyi insanlardır" (Vella, 2014, s. 863).

Öğrencilerin en çok belirttikleri olumsuz düşünce din değişikliğiydi ancak bunun yanında esaretten ve kölelikten de bahsetmişlerdi. Hristiyan oldukları için köle yapılacakları düşüncesindeydiler. Bazı öğrenciler eğer Osmanlılar kazansalardı Malta'nın Arap yapılarıyla dolacağını düşünmekteydiler. Burada Arapları ve Türkleri karıştırdıklarını görmekteyiz (Vella, 2014 , s. 865).

Yüzlerce yıllık "biz" ve "onlar" algısının yalnızca bir ders ile değişmesi mümkün değildir. Ancak bu çalışmada ders türü geleneksel tarih öğretimi yerine, yapılandırmacı yaklaşım ile kanıt temelli çalışma yapılarak tutumlar açısından bir miktar ilerleme kaydedilmişti. Bu çalışmada öğrencilere hazır toplanmış gerçekler sunulmamış, onun yerine yorum yapmalarına imkân tanınarak tarih oluşturma sürecine katılmaları sağlanmıştı. Ayrıca çalışmanın Türk öğretmenler ile danışılarak yapılması güvenilirliğini arttırmıştır. Öğrenciler bu çalışma ile "düşman" olarak bildikleri Osmanlı İmparatorluğu'na tekrar yeni bilgiler edinerek bakmışlardı. Bu çalışma Osmanlı ve Türk algısını tamamen olumlu yönde düzeltmese de bu amaçla yapılan çalışmaların etkililiği konusunda umut verici bir sonuç ortaya ortaya koymuştur (Vella, 2014, s. 866).

\section{Sonuç}

"Sınırlar Olmaksızın Avrupa'da Paylaşılan Tarih" kitabında yer alan makalelerde Osmanlı ve Türkler hakkında olumlu görüşler yer almakla beraber olumsuz görüşler ağırlıktaydı. Şimşek'in (2018) ve çalışmasında da bu açıdan benzer paralellikler görülmektedir. Şimşek'in Dünyada Türk İmajı adlı çalışmasında Avrupa Birliği ülkelerinden Almanya, Avusturya, Bulgaristan, Danimarka, Fransa, Hırvatistan, İngiltere, İspanya, Macaristan, 
Makedonya, Polonya, Romanya ve Yunanistan ülkelerinin lise tarih ders kitapları incelenmiştir.

Avrupa'da Türk demek Müslüman demek ile eşittir. Bu bağlamda Alman tarih ders kitaplarında Türk algısının Müslüman kimliği ile birlikte algılandığının altı çizilmiştir (Akif Pamuk, 2018, s. 7). İngiliz ders kitaplarında ise Osmanlı İmparatorluğu ve Türk İmparatorluğu kelimelerinin birbiri yerine kullanıldığının ancak Osmanlı demenin daha doğru olduğunun altı çizilmiştir (Kabapınar, 2018, s. 243). Yani Türk, Osmanlı ve Müslüman kelimeleri özdeş gibi algılanmaktadır ancak tarihçiler bunların ayrı unsurları ifade ettiğini anlatmaktadırlar.

İncelediğimiz kitapta özellikle ekonomi söz konusu olduğunda olumsuz görüşler ön plandaydı. Bunun en önemli nedeni Osmanlı Devleti'nin Sanayi İnkılabına ayak uyduramamış olmasıydı. Bu durumun Osmanlı Devleti'nden sonra Türkiye ve Balkanlar'a miras kaldığı belirtilmiştir. Balkanlarla ilgili olarak İspanya tarih ders kitaplarında Osmanlı Devleti'nin Balkanlar üzerinde yayılmacı hırsının olduğu belirtilmiştir. Ancak İmparatorluk dağılınca bu ülkeler bağımsızlıklarını ilan edebilmişlerdir. İspanya ders kitaplarında genel Türk ve Osmanlı algısı pozitiftir (Turan, 2018, s. 277)

Kitapta Osmanlı Devleti'nin toprakları kendine bağlayarak ilerleyişi de olumsuz anlatımlara hedef olmuş ve "invasion", "istilâ" kelimesi ile anlatılmıştır. Aynı kelime Moğol İstilasını açıklamak için de kullanılmıştı. Yani kitapta Moğol İstilâsı ile Türk ilerleyişi arasında bir ayrım yapılmamıştı. Ayrıca Kıbrıs Barış Harekatı'nın da "Türk istilası" olarak ifade edilmesi bu konudaki olumsuz imajı göstermektedir. Bulgaristan ders kitaplarında Osmanlı ilerleyişi yine "istilâ" olarak anlatılmaktadır. Hatta bu istilâlar sonucunda Balkan halklarının Avrupa dünyasından koparıldığına değinilmiştir (Hacısalihoğlu, 2018, s. 107). Makedonya tarih ders kitaplarında da Osmanlı egemenliği "işgal” olarak anlatılmaktadır (Hacısalihoğlu M. , 2018, s. 375).

Osmanlı Mimari sanatı kitapta olumlu bir anlatımla ön plana çıktı. Tarihi Mostar köprüsü önemli eserler arasında görülmekle beraber Gottfried Böhm ve oğlu Paul Böhm'ün Cologne Camii'ni tasarlarken Osmanlı mimari motiflerini benimsemeleri anlatılı. Osmanlı Devleti Avrupa kimliğine katkı sağlayan ülkeler arasında yer aldı. Özellikle Osmanlı Devleti'nin düzenli ordu sistemi buna örnek verildi. Fatih Sultan Mehmet'in İstanbul'u fethi de kitapta olumlu anlatımlar ile yer aldı.

Malta öğrencilerinin incelendiği bölümde ise öğrencilerin olumsuz algıları daha fazlaydı. En göze çarpan ise onların dinlerinin değişeceği, camilerin dönüştürüleceği ve köle yapılacaklarıydı. Buradaki kölelik algısının nedenini Yunanistan tarih ders kitaplarının incelenmesiyle öğrenmekteyiz. Onlara göre Osmanlı Türkleri fethettikleri yerlerdeki çocukları toplayıp, askeri intiyaçlarını karşılayabilmek için onları müslümanlaştırıp asker yapmaktaydılar. Böylece yeniçeri askerleri oluşturulmuştur (Özsuer, 2018, s. 534). Ayrıca Bulgaristan ders kitaplarında Osmanlı Devleti'nin ele geçirdiği ülkeleri zorla İslamlaştırdığı algısı mevcuttur (Hacısalihoğlu, 2018, s. 111).

Malta öğrencilerine yönelik yapılan araştırma bize ön yargının, güvenilir kaynaklardaki bilgilerin kullanılarak azaltılma olanağını göstermekteydi. Bu çalışma ile kitapta yer alan makalelerdeki Osmanlı ve Türk imajına Avrupa'nın gözüyle bakmaya, aslında bir yönüyle 
başkasının ayakkabısını giymeye çalıştık. Burada amacımız kendimizi başkalarının gözüyle değerlendirmek değil onların bakış açılarını kavramaktı. Tarihçiler olarak Osmanlı ve Türkler adına sahip olunan ön yargı ve varsayımların muhatabıyız. Bunları azaltabilmek için öncelikle bu fikirlerden haberdar olmalıyız. Farklı bakış açılarını anlayarak, belirsizliğe tahammülü öğrenerek ve tarihte tamamen masum olabilecek çok az sayıda kişi ve olayın olabileceğini göz önünde tutarak güvenilir kaynaklar ile tarih alanında etkili çalışmalar ortaya koyabiliriz.

\section{Kaynakça}

Pamuk, A., Pamuk, i. (2018). Almanya lise tarih ders kitaplarında Türk imajı. A. Şimşek (Ed.), Dünyada Türk Imajı, Tarih Ders Kitaplarındaki Durum. Ankara: Pegem.

Ataman, B. C. (2014). Histoire de la Revulation Industrielle a le'poqueOttomane et en Tuquie. Strasbourg: Council of Europe.

Criacono, S. (2014). European expansion, colonialism and the "rise of the West": A divergence? Shared Histories for Europe Without Dividing Lines. içinde Strasbourg: Council of Europe.

Ersoy Hacısalihoğlu, N. (2018). Bulgaristan lise tarih ders kitaplarında Türk imajı. A. Şimşek (Ed.), Dünyada Türk Imajı, Tarih Ders Kitaplarındaki Durum. Ankara: Pegem.

Hacısalihoğlu, M. (2018). Makedonya Lise Tarih Ders Kitaplarında Türk İmajı. A. Şimşek (Ed.), Dünyada Tüek Imajı. Ankara: Pegem.

Juneja, M. (2014). Global Boundaries, Local Frontiers İslamic Art in Museums. Shared Histories for Europe Without Dividing Lines. içinde Strasbourg: Council of Europe.

Kabapınar, Y. (2018). İngiltere lise tarih ders kitaplarında Osmanlı ve Türk imajı. A. Şimşek (Ed.), Dünyada Türk Imajı, Lise Tarih Ders Kitaplarındaki Durum (s. 243). Ankara: Pegem.

Kacır, T. İ. (2018). Avusturya lise tarih ders kitaplarında Türk imajı. A. Şimşek (Ed.), Dünyada Türk Imajı, Tarih Ders Kitaplarındaki Durum. Ankara: Pegem.

Kaelbie, H. (2014). The impact of the industrial revolution, a general introduction. Shared Histories Without Dividing Lines. içinde Strasbourg: Council of Europe.

Manea, M. (2014). Reflection on the industrial revolution in Romenia and SE Europe: between specificity and necessity- why so late? Shared Histories for Europe Without Dividing Lines. içinde Strasbourg: Council of Europe.

Mazarakis, P. (2014). Imagining the Balkans, Identities and memory in the long 19th Century. Shared Histories for Europe Without Dividing Lines. içinde Strasbourg: Council of Europe.

Özsuer, E. (2018). Yunanistan lise tarih ders kitaplarında Türk imajı. A. Şimşek (Ed.), Dünyada Türk Imajı, Tarih Ders Kitaplarındaki Durum. Ankara: Pegem. 
Sachsenmaier, D. (2014). European historical identities and the World. Shared Histories for Europe Without Dividing Lines. içinde Strasbourg: Council of Europe.

Samardžić-Marković, S. (2014). Preface. Shared Histories for Europe Without Dividing Lines.

Şimşek, H., ve Yıldırım, A. (2018). Sosyal Bilimlerde Nitel Araştırma Yöntemleri. Ankara: Seçkin.

The Development of Education, A Brief Introductıon. (2014). Shared Histories for Europe Without Dividing Lines. içinde Strasbourg: Council of Europe.

Turan, T. (2018). İspanya lise tarih ders kitaplarında Türk İmajı. A. Şimşek (Ed.), Dünyada Türk Imajı, Tarih Ders Kitaplarındaki Durum. Ankara: Pegem.

Vella, Y. (2014). Is it possible to change student's attitute towards "the other" through history teaching. Shared Histories for Europe Without Dividing Lines. içinde Strasbourg: Council of Europe.

Vries, P. (2014). Encounters between Europe and the World. P. Vries (Ed.), Shared Histories for Europe Without Dividing Lines. Strasbourg: Council of Europe.

Welzel, B. (2014). Living together in dignity. Shared Histories for Europe Without Dividing Lines. içinde Strasbourg: Council of Europe.

Yazıcı, S. (2018). Fransa lise tarih ders kitaplarında Osmanlı ve Türk imajı. A. Şimşek (Ed.), Dünyada Türk Imajı, Tarih Ders Kitaplarındaki Durm. Ankara: Pegem. 